\title{
SIKAP DAN MOTIVASI PETANI DALAM BUDIDAYA TANAMAN SEMANGKA DI LAHAN PASIR PANTAI, KABUPATEN PURWOREJO, JAWA TENGAH
}

\author{
Arta Kusumaningrum $^{1^{*}}$, Fitri Rahmawati $^{2}$ \\ ${ }^{1}$ Program Studi Agribisnis Universitas Muhammadiyah Purworejo \\ ${ }^{2}$ Program Studi Manajemen Universitas Muhammadiyah Purworejo \\ Jl. KHA Dahlan No. 3 \& 6, Purworejo \\ *Corresponding author: arta.kusumaningrum@gmail.com
}

\begin{abstract}
Attitude and motivation are two important components in cultivating watermelon plants in coastal sandy land, Purworejo Regency. There were 2 objectives of this study, namely 1) to determine the attitudes of farmers in the cultivation of watermelons in coastal sandy land, Purworejo Regency and 2) to determine the motivation of farmers in watermelon cultivation in coastal sandy land, Purworejo Regency. Respondents involved in this study were 60 farmers in Grabag District, Ngombol District, and Purwodadi District. The research was conducted by purposive sampling, which was carried out in accordance with the research objectives. The analysis used was Likert scale and class intervals. They were used to determine the level of attitude and motivation of farmers in watermelon cultivation in coastal sandy land, Purworejo Regency. The Likert scale used were the SS scale (Strongly Agree), S (Agree), R (Doubtful), TS (Disagree), STS (Strongly Disagree) while class intervals were divided into 3 categories, namely high, medium, and low categories. The results of this study were 1) the attitude of farmers in watermelon cultivation in the coastal sandy land of Purworejo Regency, Central Java was medium. This study showed that many farmers had a tendency to utilize coastal sandy land for watermelons cultivation in Purworejo Regency and 2) the motivation of farmers in cultivating watermelons in coastal sandy land in Purworejo Regency, Central Java was medium as well. Therefore, it revealed that many farmers had been motivated to utilize coastal sandy land to cultivate watermelon plants in Purworejo Regency.
\end{abstract}

Keywords: attitude, motivation, cultivation, watermelon

\begin{abstract}
Abstrak: Sikap dan motivasi merupakan dua komponen penting yang membentuk petani dalam melakukan budidaya tanaman semangka di lahan pasir pantai, Kabupaten Purworejo. Dalam penelitian ini memiliki 2 tujuan yaitu 1) untuk mengetahui sikap petani dalam budidaya tanaman semangka di lahan pasir pantai, Kabupaten Purworejo dan 2) untuk mengetahui motivasi petani dalam budidaya tanaman semangka di lahan pasir pantai, Kabupaten Purworejo. Responden dalam penelitian ini total 60 petani yang terdapat di Kecamatan Grabag, Kecamatan Ngombol, dan Kecamatan Purwodadi. Penelitian dilakukan dengan purposive sampling yaitu dilakukan sesuai dengan tujuan penelitian. Analisis yang digunakan dengan menggunakan skala likert dan interval kelas. Analisis skala likert dan interval kelas digunakan untuk mengetahui tingkat sikap dan motivasi petani dalam budidaya tanaman semangka di lahan pasir pantai, Kabupaten Purworejo. Skala likert yang digunakan dengan skala SS (Sangat Setuju), S (Setuju), R (Ragu-Ragu), TS (Tidak Setuju), STS (Sangat Tidak Setuju). Untuk interval kelas dibagi menjadi 3 kategori yaitu kategori tinggi, sedang, dan rendah. Hasil penelitian ini yaitu 1) Sikap petani pada budidaya tanaman semangka di lahan pasir pantai Kabupaten Purworejo, Jawa Tengah adalah sedang. Hal ini menunjukkan sudah banyak petani yang memiliki kecenderungan memanfaatkan lahan pasir pantai untuk budidaya tanaman semangka di Kabupaten Purworejo dan 2)
\end{abstract}


Motivasi petani pada budidaya tanaman semangka di lahan pasir pantai Kabupaten Purworejo, Jawa Tengah adalah sedang. Hal ini menunjukkan sudah banyak petani yang terdorong memanfaatkan lahan pasir pantai untuk budidaya tanaman semangka di Kabupaten Purworejo.

Kata Kunci: sikap, motivasi, budidaya, semangka

\section{PENDAHULUAN}

Sikap dapat didefinisikan sebagai perasaan, pikiran, dan kecenderungan seseorang akan menyikapi suatu hal. Menurut Setyowati et al. (2020) sikap mengandung tiga komponen yaitu komponen pengetahuan (kognitif), komponen perasaan-perasaan (afektif), dan komponen kecenderungan dalam bertindak (konatif). Ketiga komponen tersebut yang akan menjadi pedoman sikap dalam penelitian ini.

Menurut Miftakhul et al. (2017) bahwa ekspresi kepercayaan (kognitif) merupakan pengetahuan dan informasi mengenai obyek yang menyangkut fakta-fakta, pengetahuan, persepsi dan keyakinan tentang obyek, berisi kepercayaan mengenai obyek, sikap yang diperoleh dari apa yang dilihat dan diketahui, sehingga terbentuk ide, gagasan, atau karakteristik umum mengenai sikap. Selanjutnya kecenderungan berperilaku (konatif) merupakan kesiapan merespon obyek atau kecenderungan bertindak dengan obyek sikap. Berdasarkan hasil kerja pikir dan pengetahuan ditunjang dengan warna emosi timbul suatu kecenderungan untuk bertindak. Dapat berupa tingkah laku yang tampak, pernyataan atau ucapan dan ekspresi. Bentuk kecenderungan bertindak dapat berupa tingkah laku yang tampak, pernyataan atau ucapan ekspresi atau mimik. Kecenderungan bersifat subyektif dan sangat dipengaruhi oleh emosi seseorang yang dianggap atau sesuai dengan perasaan yang akan menjadi bentuk kecenderungan terhadap obyek.

Selain sikap, penelitian ini mengkaji mengenai motivasi petani pada budidaya tanaman semangka di lahan pasir pantai, Kabupaten Purworejo. Motivasi merupakan suatu dorongan untuk melakukan sesuatu. Menurut Sukanata et al. (2015) dalam suatu motivasi individu merupakan unsur yang sangat penting dalam proses yang lebih baik kearah yang lebih kompetensi. Penelitian ini menggunakan teori kebutuhan Maslow. Penelitian ini mengkaji bagaimana motivasi petani apabila dilihat dari kelima aspek teori kebutuhan yang mendasar. Teori kebutuhan oleh Maslow yaitu fisiologis, keamanan, kasih sayang, harga diri, dan aktualisasi diri. Selain itu, Ife dan Tesoriero (2008) berpendapat bahwa gagasan kebutuhan manusia mengacu kepada hal-hal yang harus dimiliki seperti pangan, papan, air, keamanan dan sebagainya.

Menurut Hariadi (2011) menyebutkan bahwa semangat disebabkan oleh kebutuhan atau keinginan, sehingga memberikan energi perilaku yang berkaitan dengan tujuan dan hasil, dan didukung oleh reward yang kemudian memberikan umpan balik untuk memodifikasi kebutuhan atau tujuan. Sedangkan menurut Rahmawati et al (2015) bahwa dengan adanya motivasi maka tujuan yang diinginkan ini tentunya harus dibarengi dengan kesiapan dari dalam diri untuk mendorong tingkah laku untuk berbuat sesuatu.

Kabupaten Purworejo yang terletak di wilayah Jawa Tengah memiliki demografi yang menarik, selain terdiri dari dataran rendah dan dataran tinggi juga memiliki wilayah pesisir. Wilayah pesisir yang berbatasan dengan daratan ini memiliki luasan lahan yang cukup luas. Ini merupakan salah satu potensi alam yang harus dimaksimalkan penggunaannya guna menunjang peningkatan produktivitas hasil pertanian. Walaupun daerah pesisir kandungan tanahnya mengandung pasir tetapi banyak komoditas yang dapat dibudidayakan. Seperti yang dikatakan Kusumaningrum dan Widiyantono (2018) bahwa lahan pasir merupakan lahan marginal karena struktur lahan pasir pantai lebih banyak terdiri dari unsur pasir dibanding dengan tanah itu sendiri.

Komoditas yang dapat dibudidayakan di lahan pasir pantai salah satunya adalah tanaman semangka. Tanaman semangka merupakan buah yang banyak gemari khususnya di wilayah Kabupaten Purworejo, Jawa Tengah. Buah semangka memiliki kandungan mineral yang dibutuhkan oleh tubuh. Menurut Khusna et al. (2016) bahwa buah semangka terdiri dari berbagai varietas sehingga memiliki pangsa 
pasarnya sendiri. Selain itu dari penelitian Wilastinova (2012), perlu adanya pola tanam dan grading buah semangka untuk meningkatkan pendapatan petani. Pola tanam bertujuan untuk menghindari panen yang melimpah yang dapat menyebabkan harga buah semangka menjadi rendah, selain itu penggunaan pupuk kompos juga berpengaruh pada produksi buah semangka di lahan pasir pantai. Hal ini dikarenakan sifat dari pupuk kompos yang menjaga kadar lengas tanah sehingga mengurangi penguapan kandungan air yang berlebih.

Dari uraian kajian di atas diketahui bahwa tanaman semangka merupakan komoditas yang menjanjikan untuk petani. Dalam penelitian ini, peneliti ingin mengetahui:

1. Untuk mengetahui sikap petani dalam budidaya tanaman semangka di lahan pasir pantai, Kabupaten Purworejo.

2. Untuk mengetahui motivasi petani dalam budidaya tanaman semangka di lahan pasir pantai, Kabupaten Purworejo.

\section{METODE PENELITIAN}

Metode yang digunakan dalam penelitian ini adalah mixed method menggabungkan metode kuantitatif dan kualitatif dalam satu penelitian. Menurut Creswell (2012), mixed method yaitu mencampurkan metode-metode sekaligus pendekatan yang berhubungan dengan metode tersebut seperti menggabungkan metode observasi dan wawancara dengan metode survei. Seperti pendapat Bryman (2016), melalui mixed method menggunakan gabungan strategi untuk menemukan hasil dari penelitian.

Untuk metode kuantitatif peneliti menggunakan data-data yang bersifat angka dan dapat dihitung. Untuk penelitian kualitatif merupakan proses analisis data yang dilakukan sejak peneliti mulai mengumpulkan data selama di lapangan sampai dengan semua data terkumpul (Djamal, 2015). Analisis kualitatif mendukung dengan memberikan penjelasan atau reasoning sesuai dengan keadaan di lapangan.

Data yang digunakan dalam penelitian ini adalah data primer dan data sekunder. Pengumpulan data Primer dalam penelitian ini adalah wawancara mendalam (indepth interview) yaitu berupa dialog baik secara individu maupun kelompok dengan informan dan responden sedangkan data sekunder diperoleh melalui laporan-laporan tahunan tertulis lembaga atau institusi yang terkait dalam penelitian ini (Zainal dan Cepriadi, 2015).

Sampel yang diambil berdasarkan purposive sampling adalah sesuatu dengan tujuan penelitian. Jumlah total sampel yang diambil dalam penelitian ini adalah 60 sampel di Kecamatan Grabag, Kecamatan Ngombol, dan Kecamatan Purwodadi. Seperti yang dinyatakan oleh Sugiyono (2010) bahwa sampling purposive adalah teknik pengambilan sampel dengan pertimbangan tertentu. Untuk mengetahui sikap dan motivasi petani pada budidaya tanaman semangka di lahan pasir pantai, Kabupaten Purworejo menggunakan skala likert dan interval kelas.

Menurut Morissan (2016), pada skala likert peneliti harus merumuskan sejumlah pernyataan mengenai suatu topik tertentu dan responden diminta memilih apakah ia sangat setuju, setuju, ragu-ragu/netral, tidak setuju, atau sangat tidak setuju. Setiap pilihan jawaban memiliki bobot yang berbeda, dan seluruh jawaban responden dijumlahkan berdasarkan bobotnya sehingga menghasilkan suatu skor tunggal mengenai suatu topik tertentu.

Adapun dalam penelitian ini pengukuran skala likert dengan menggunakan skor yang digunakan dalam kuesioner adalah SS (Sangat Setuju) skor 5, S (Setuju) skor 4, R (RaguRagu) skor 3, TS (Tidak Setuju) skor 2, dan STS (Sangat Tidak Setuju) skor 1. Untuk interval kelas digunakan untuk membagi hasil total yang diperoleh dari skala likert dibagi menjadi 3 kategori yaitu kategori tinggi, sedang, dan rendah.

\section{HASIL DAN PEMBAHASAN}

\section{Sikap Petani dalam Budidaya Tanaman Semangka di Lahan Pasir Pantai, Kabupaten Purworejo}

Dari hasil penelitian didapatkan hasil sikap petani dalam budidaya tanaman semangka di lahan pasir pantai Kabupaten Purworejo sebagai berikut: 
Tabel 1. Sikap kognitif petani pada budidaya tanaman semangka di lahan pasir pantai, Kabupaten Purworejo

\begin{tabular}{|c|c|c|}
\hline Pernyataan & Rata-rata skor & Persentase (\%) \\
\hline Petani mengetahui cara melakukan budidaya tanaman semangka. & 2,53 & 7,03 \\
\hline $\begin{array}{l}\text { 2. Budidaya tanaman semangka dapat dilakukan di lahan pasir } \\
\text { pantai. }\end{array}$ & 2,33 & 6,49 \\
\hline $\begin{array}{l}\text { 3. Budidaya tanaman semangka tidak memerlukan perawatan yang } \\
\text { rumit. }\end{array}$ & 3,35 & 9,32 \\
\hline $\begin{array}{l}\text { 4. Budidaya tanaman semangka tidak memerlukan waktu tanam } \\
\text { yang lama. }\end{array}$ & 4,40 & 12,23 \\
\hline $\begin{array}{l}\text { 5. Petani melihat peluang adanya lahan pasir pantai untuk budidaya } \\
\text { tanaman semangka. }\end{array}$ & 4,57 & 12,71 \\
\hline $\begin{array}{l}\text { 6. Petani memiliki pengalaman untuk melakukan budidaya tanaman } \\
\text { semangka. }\end{array}$ & 2,22 & 6,17 \\
\hline $\begin{array}{l}\text { 7. Lahan pasir pantai dapat digunakan untuk budidaya tanaman } \\
\text { semangka. }\end{array}$ & 2,58 & 7,17 \\
\hline $\begin{array}{l}\text { 8. Petani mengetahui bahwa bertanam semangka di lahan pasir } \\
\text { pantai tidak kesulitan dalam hal pengairan. }\end{array}$ & 2,48 & 6,89 \\
\hline $\begin{array}{l}\text { 9. Petani mengetahui bahwa bertanam semangka di lahan pasir } \\
\text { pantai tidak kesulitan dalam hal pemupukan. }\end{array}$ & 2,22 & 6,17 \\
\hline $\begin{array}{l}\text { 10. Petani semangka mengetahui bahwa tanaman semangka tahan } \\
\text { terhadap hama dan penyakit. }\end{array}$ & 2,57 & 7,16 \\
\hline $\begin{array}{l}\text { 11. Petani semangka mengetahui bahwa bertanam semangka } \\
\text { mendapatkan keuntungan yang banyak. }\end{array}$ & 4,13 & 11,49 \\
\hline $\begin{array}{l}\text { 12. Petani semangka mengetahui bahwa bertanam semangka } \\
\text { memerlukan modal yang sedikit. }\end{array}$ & 2,58 & 7,17 \\
\hline Total & 35,97 & 100 \\
\hline
\end{tabular}

Sumber: Analisis Data Primer, 2019

Berdasarkan Tabel 1 dapat diketahui bahwa persentase tertinggi dalam sikap kognitif petani pada budidaya tanaman semangka di lahan pasir pantai Kabupaten Purworejo adalah petani melihat peluang adanya lahan pasir untuk budidaya tanaman semangka yaitu sebesar $12,71 \%$. Kemudian persentase terbesar ke dua yaitu sebesar $12,23 \%$ bahwa petani mengetahui budidaya tanaman semangka tidak memerlukan waktu tanam yang lama dan selain itu juga petani semangka mengetahui bahwa bertanam semangka mendapatkan keuntungan yang banyak yaitu sebesar 11,49\%.

Dari pernyataan aspek sikap kognitif petani dalam budidaya tanaman semangka di lahan pasir pantai Kabupaten Purworejo bahwa petani sudah mengetahui manfaat lahan pasir pantai dapat digunakan budidaya tanaman semangka, untuk melakukan budidaya tanaman semangka di lahan pasir pantai juga tidak memerlukan perawatan yang sulit, dan petani mengetahui bahwa untuk budidaya tanaman semangka tidak perlu waktu tanam yang lama

Berdasarkan Tabel 2 terlihat bahwa persentase terbesar untuk sikap afektif petani semangka senang menanam semangka karena dapat mencukupi gizi keluarga sebesar 8,24\%, petani merasa senang dengan menanam semangka karena mudah untuk dijual yaitu sebesar 8,18, dan petani merasa senang melakukan budidaya tanaman semangka di lahan pasir pantai $8,15 \%$. Hal ini menunjukkan petani merasa senang dengan kemudahan yang didapat untuk melakukan budidaya tanaman semangka di lahan pasir pantai.

Tabel 3 menunjukkan sikap konatif petani pada budidaya tanaman semangka di lahan pasir pantai Kabupaten Purworejo. Petani akan melakukan pemilihan benih yang unggul dalam budidaya tanaman semangka di lahan pasir pantai yaitu sebesar $10,42 \%$, petani akan melakukan proses grading untuk menentukan harga semangka di pasar $10,42 \%$, petani akan melakukan pengairan yang tepat dalam budidaya tanaman semangka di lahan pasir pantai $10,35 \%$, dan petani akan melakukan pemeliharaan yang baik dalam budidaya semangka di lahan pasir pantai $10,31 \%$. Hal ini menunjukkan tindakan yang akan dilakukan oleh petani di lahan pasir pantai, Kabupaten Purworejo yaitu tetap akan melakukan budidaya tanaman semangka. 
Tabel 2. Sikap afektif petani pada budidaya tanaman semangka di lahan pasir pantai, Kabupaten Purworejo

\begin{tabular}{|c|c|c|}
\hline Pernyataan & $\begin{array}{l}\text { Rata- } \\
\text { rata skor }\end{array}$ & $\begin{array}{l}\text { Persentase } \\
(\%)\end{array}$ \\
\hline Petani senang melakukan budidaya tanaman semangka di lahan pasir pantai. & 4,45 & 8,15 \\
\hline $\begin{array}{l}\text { 2. Petani merasa senang dengan hasil yang diperoleh dari budidaya tanaman } \\
\text { semangka di lahan pasir pantai. }\end{array}$ & 4 & 7,33 \\
\hline $\begin{array}{l}\text { 3. Petani merasa senang dengan menanam tanaman semangka di lahan pasir } \\
\text { pantai karena tingkat kerugian akibat serangan hama sedikit. }\end{array}$ & 2,46 & 4,50 \\
\hline $\begin{array}{l}\text { 4. Petani merasa senang dengan menanam tanaman semangka karena banyak } \\
\text { petani lain yang menanam. }\end{array}$ & 4,17 & 7,63 \\
\hline $\begin{array}{l}\text { 5. Petani merasa senang dengan menanam semangka untuk memenuhi } \\
\text { kebutuhan gizi keluarga. }\end{array}$ & 4,38 & 8,03 \\
\hline $\begin{array}{l}\text { 6. Petani merasa senang dengan menanam tanaman semangka karena } \\
\text { menguntungkan. }\end{array}$ & 4,35 & 7,97 \\
\hline 7. Petani merasa senang dengan menanam semangka karena mudah dijual. & 4,47 & 8,18 \\
\hline $\begin{array}{l}\text { 8. Petani senang menanam tanaman semangka karena tidak kesulitan dalam } \\
\text { pengairan. }\end{array}$ & 4,28 & 7,85 \\
\hline 9. Petani senang menanam semangka karena tidak kesulitan dalam pemupukan. & 4,28 & 7,85 \\
\hline $\begin{array}{l}\text { 10. Petani semangka senang menanam semangka karena mendapat untung } \\
\text { banyak. }\end{array}$ & 3,93 & 7,21 \\
\hline $\begin{array}{l}\text { 11. Petani semangka senang menanam semangka karena tahan terhadap hama dan } \\
\text { penyakit. }\end{array}$ & 2,38 & 4,37 \\
\hline $\begin{array}{l}\text { 12. Petani semangka senang menanam semangka karena modal produksi tidak } \\
\text { banyak. }\end{array}$ & 4,72 & 4,97 \\
\hline $\begin{array}{l}\text { 13. Petani semangka senang menanam semangka karena banyak sesama petani } \\
\text { yang menanam semangka. }\end{array}$ & 4,22 & 7,72 \\
\hline $\begin{array}{l}\text { 14. Petani semangka senang menanam semangka karena dapat mencukupi gizi } \\
\text { keluarga. }\end{array}$ & 4,5 & 8,24 \\
\hline Total & 54,59 & 100 \\
\hline
\end{tabular}

Sumber: Analisis Data Primer, 2019

Tabel 3. Sikap konatif petani pada budidaya tanaman semangka di lahan pasir pantai, Kabupaten Purworejo

\begin{tabular}{|c|c|c|}
\hline Pernyataan & $\begin{array}{l}\text { Rata-rata } \\
\text { skor }\end{array}$ & $\begin{array}{l}\text { Persentase } \\
(\%)\end{array}$ \\
\hline 1. Petani akan melakukan budidaya tanaman semangka di lahan pasir pantai. & 4,58 & 9,88 \\
\hline $\begin{array}{l}\text { 2. Petani akan melakukan budidaya tanaman semangka secara tepat untuk } \\
\text { pemupukan. }\end{array}$ & 4,75 & 10,24 \\
\hline $\begin{array}{l}\text { 3. Petani akan melakukan pemilihan benih yang unggul dalam budidaya } \\
\text { tanaman semangka di lahan pasir pantai. }\end{array}$ & 4,83 & 10,42 \\
\hline $\begin{array}{l}\text { 4. Petani akan melakukan pengairan yang tepat dalam budidaya tanaman } \\
\text { semangka di lahan pasir pantai. }\end{array}$ & 4,8 & 10,35 \\
\hline $\begin{array}{l}\text { 5. Petani akan melakukan pemeliharaan yang baik dalam budidaya semangka di } \\
\text { lahan pasir pantai. }\end{array}$ & 4,78 & 10,31 \\
\hline $\begin{array}{l}\text { 6. Petani akan melakukan pemanenan sesuai dengan umur tanaman pada } \\
\text { tanaman semangka di lahan pasir pantai. }\end{array}$ & 4,7 & 10,13 \\
\hline $\begin{array}{l}\text { 7. Petani akan melakukan proses pasca panen agar tanaman semangka tidak } \\
\text { mudah busuk dan rusak. }\end{array}$ & 4,53 & 9,77 \\
\hline $\begin{array}{l}\text { 8. Petani akan melakukan proses grading untuk menentukan harga semangka di } \\
\text { pasar. }\end{array}$ & 4,83 & 10,42 \\
\hline $\begin{array}{l}\text { 9. Petani akan mengajak petani lain untuk menanam semangka karena lebih } \\
\text { menguntungkan. }\end{array}$ & 4,22 & 9,10 \\
\hline $\begin{array}{l}\text { 10. Petani akan mengembangkan usahatani semangka karena dapat memenuhi } \\
\text { kebutuhan gizi keluarga. }\end{array}$ & 4,35 & 9,37 \\
\hline Total & 46,38 & 100 \\
\hline
\end{tabular}

Sumber: Analisis Data Primer, 2019 
Kusumaningrum, A., Rahmawati, F.: Sikap dan Motivasi Petani ...

Tabel 4. Tingkat sikap petani pada budidaya tanaman semangka di lahan pasir pantai, Kabupaten Purworejo

\begin{tabular}{cccc}
\hline Kategori & Interval Kelas & Jumlah & Persentase \\
\hline Rendah & $41,33-44,44$ & 16 & 26,67 \\
Sedang & $44,44-47,55$ & 36 & 60 \\
Tinggi & $47,56-50,66$ & 8 & 13,33 \\
\hline & & 60 & 100,00 \\
\hline
\end{tabular}

Sumber: Analisis Data Primer, 2019

Tabel 5. Kebutuhan fisiologis petani pada budidaya tanaman semangka di lahan pasir pantai, Kabupaten Purworejo

\begin{tabular}{|c|c|c|}
\hline Pernyataan & Rata-rata skor & Persentase $(\%)$ \\
\hline $\begin{array}{l}\text { 1. Adanya dorongan petani untuk budidaya semangka menjadikan } \\
\text { petani memperoleh penghasilan tetap. }\end{array}$ & 3,33 & 18,26 \\
\hline $\begin{array}{l}\text { 2. Adanya dorongan petani untuk budidaya semangka menjadikan } \\
\text { petani dapat memenuhi kebutuhan pangan. }\end{array}$ & 3,7 & 20,27 \\
\hline $\begin{array}{l}\text { 3. Adanya dorongan petani untuk budidaya semangka menjadikan } \\
\text { petani dapat memenuhi kebutuhan sandang. }\end{array}$ & 3,62 & 19,82 \\
\hline $\begin{array}{l}\text { 4. Adanya dorongan petani untuk budidaya semangka menjadikan } \\
\text { petani dapat memenuhi kebutuhan papan. }\end{array}$ & 3,47 & 18,99 \\
\hline $\begin{array}{l}\text { 5. Adanya dorongan petani untuk budidaya semangka menjadi } \\
\text { petani dapat memenuhi kebutuhan gizi keluarga. }\end{array}$ & 4,13 & 22,65 \\
\hline Total & 18,25 & 100 \\
\hline
\end{tabular}

Sumber: Analisis Data Primer, 2019

Tabel 4 menunjukkan tingkat sikap petani pada budidaya tanaman semangka di lahan pasir pantai, Kabupaten Purworejo yaitu tergolong kategori sedang dengan persentase sebesar $60 \%$. Hal ini dikarenakan banyak petani di lahan pasir pantai Kabupaten Purworejo yang sudah melakukan budidaya tanaman semangka. Petani memilih untuk menanam tanaman semangka di lahan pasir pantai untuk memanfaatkan lahan pasir pantai agar menjadi lahan yang produktif sehingga dapat meningkatkan penghasilan dan keuntungan petani. Hal ini sesuai dengan hasil penelitian yang dilakukan oleh Prilierdi et al. (2015) bahwa perkembangan usahatani semangka selalu meningkat dan memiliki hubungan terhadap pendapatan.

\section{Motivasi Petani pada Budidaya Tanaman Semangka di Lahan Pasir Pantai, Kabupaten Purworejo}

Dari hasil penelitian didapatkan hasil motivasi petani pada budidaya tanaman semangka di lahan pasir pantai, Kabupaten Purworejo seperti dalam Tabel 5.

Tabel 5 menyajikan kebutuhan fisiologis petani pada budidaya tanaman semangka di lahan pasir pantai Kabupaten Purworejo.
Sebesar 22,65\% menyatakan adanya dorongan untuk budidaya semangka menjadikan petani dapat memenuhi kebutuhan gizi keluarga, sebesar $20,27 \%$ menyatakan bahwa adanya dorongan petani untuk budidaya semangka menjadikan petani dapat memenuhi kebutuhan pangan, sebesar 19,82\% menyatakan bahwa adanya dorongan petani untuk budidaya semangka menjadikan petani dapat memenuhi kebutuhan sandang. Hal ini menunjukkan bahwa dorongan petani untuk memenuhi kebutuhan fisiologis dapat terpenuhi dengan melakukan budidaya tanaman semangka di lahan pasir pantai Kabupaten Purworejo.

Berdasarkan Tabel 6 kebutuhan keamanan petani pada budidaya tanaman semangka di lahan pasir pantai Kabupaten Purworejo yaitu sebesar 23,93\% menyatakan bahwa adanya dorongan untuk menanam tanaman semangka di lahan pasir pantai karena petani merasa aman, sebesar $23,66 \%$ menyatakan bahwa adanya dorongan untuk menanam tanaman semangka di lahan pasir pantai karena petani merasa nyaman, dan sebesar $23,03 \%$ menyatakan bahwa adanya dorongan untuk menanam tanaman semangka di lahan pasir pantai karena dapat dipantau tidak jauh dengan jarak rumah. 
Tabel 6. Kebutuhan keamanan petani pada budidaya tanaman semangka di lahan pasir pantai, Kabupaten Purworejo

\begin{tabular}{|c|c|c|}
\hline Pernyataan & Rata-rata skor & Persentase $(\%)$ \\
\hline $\begin{array}{l}\text { 1. Adanya dorongan untuk menanam tanaman semangka di lahan } \\
\text { pasir pantai karena petani merasa nyaman. }\end{array}$ & 4,38 & 23,66 \\
\hline $\begin{array}{l}\text { 2. Adanya dorongan untuk menanam tanaman semangka di lahan } \\
\text { pasir pantai karena petani merasa aman. }\end{array}$ & 4,43 & 23,93 \\
\hline $\begin{array}{l}\text { 3. Adanya dorongan untuk menanam tanaman semangka di lahan } \\
\text { pasir pantai karena tidak ada gangguan berupa hewan. }\end{array}$ & 3,12 & 16,82 \\
\hline $\begin{array}{l}\text { 4. Adanya dorongan untuk menanam tanaman semangka di lahan } \\
\text { pasir pantai karena tidak ada yang merusak tanaman. }\end{array}$ & 2,33 & 12,59 \\
\hline $\begin{array}{l}\text { 5. Adanya dorongan untuk menanam tanaman semangka di lahan } \\
\text { pasir pantai karena dapat dipantau tidak jauh dengan jarak rumah. }\end{array}$ & 4,27 & 23,03 \\
\hline Total & 18,53 & 100 \\
\hline
\end{tabular}

Sumber: Analisis Data Primer, 2019

Tabel 7. Kebutuhan kasih sayang petani pada budidaya tanaman semangka di lahan pasir pantai, Kabupaten Purworejo

\begin{tabular}{|c|c|c|}
\hline Pernyataan & Rata-rata skor & Persentase $(\%)$ \\
\hline $\begin{array}{l}\text { 1. Dengan menanam tanaman semangka petani merasakan adanya } \\
\text { kekompakan dengan sesama petani semangka di lahan pasir } \\
\text { pantai. }\end{array}$ & 4,52 & 21,01 \\
\hline $\begin{array}{l}\text { 2. Dengan menanam tanaman semangka, petani merasakan diterima } \\
\text { oleh lingkungan sekitar di lahan pasir pantai. }\end{array}$ & 4,35 & 20,23 \\
\hline $\begin{array}{l}\text { 3. Dengan menanam tanaman semangka petani sering diajak untuk } \\
\text { kumpul kelompok tani membahas budidaya tanaman semangka. }\end{array}$ & 4,22 & 19,61 \\
\hline $\begin{array}{l}\text { 4. Dengan menanam tanaman semangka petani mendapatkan } \\
\text { hubungan yang baik dengan tengkulak buah semangka. }\end{array}$ & 4,13 & 19,22 \\
\hline $\begin{array}{l}\text { 5. Dengan menanam tanaman semangka petani mendapatkan } \\
\text { hubungan yang baik dengan penyuluh lapangan. }\end{array}$ & 4,28 & 19,92 \\
\hline Total & 21,5 & 100 \\
\hline
\end{tabular}

Sumber: Analisis Data Primer, 2019

Tabel 8. Kebutuhan harga diri petani pada budidaya tanaman semangka di lahan pasir pantai, Kabupaten Purworejo

\begin{tabular}{|c|c|c|}
\hline Pernyataan & Rata-rata skor & Persentase $(\%)$ \\
\hline Dengan menanam tanaman semangka petani lebih percaya diri. & 4,08 & 18,38 \\
\hline $\begin{array}{l}\text { 2. Dengan menanam tanaman semangka petani lebih terdorong } \\
\text { untuk meningkatkan kemampuan dirinya dalam budidaya } \\
\text { tanaman semangka di lahan pasir. }\end{array}$ & 4,48 & 20,18 \\
\hline $\begin{array}{l}\text { 3. Dengan menanam tanaman semangka petani lebih terdorong } \\
\text { untuk meningkatkan pengetahuannya. }\end{array}$ & 4,65 & 20,93 \\
\hline $\begin{array}{l}\text { 4. Dengan menanam tanaman semangka petani lebih terdorong } \\
\text { untuk meningkatkan ketrampilannya. }\end{array}$ & 4,67 & 21,00 \\
\hline $\begin{array}{l}\text { 5. Dengan menanam tanaman semangka petani tidak terkucilkan di } \\
\text { lingkungan sekitar mereka. }\end{array}$ & 4,33 & 19,50 \\
\hline Total & 22,22 & 100 \\
\hline
\end{tabular}

Sumber: Analisis Data Primer, 2019

Pada Tabel 7 tentang kebutuhan kasih sayang petani pada budidaya tanaman semangka di lahan pasir pantai Kabupaten Purworejo menyatakan bahwa sebesar 21,01\% dengan menanam tanaman semangka petani merasakan adanya kekompakan dengan sesama petani semangka di lahan pasir pantai, sebesar
20,23 \% menyatakan dengan menanam tanaman semangka petani merasakan diterima oleh lingkungan sekitar di lahan pasir pantai, dan sebesar 19,92 menyatakan bahwa dengan menanam tanaman semangka petani mendapatkan hubungan yang baik dengan penyuluh lapangan. Hal ini menunjukkan 
bahwa perlunya kebutuhan hubungan dengan petani lain untuk mendapatkan pengakuan, hubungan baik, bertemu dengan petani yang lain untuk mendapatkan informasi seputar budidaya semangka sehingga menjadikan dorongan petani untuk tetap berbudidaya tanaman semangka di lahan pasir pantai, Kabupaten Purworejo.

Pada Tabel 8 menunjukkan mengenai kebutuhan harga diri petani pada budidaya tanaman semangka di lahan pasir pantai, Kabupaten Purworejo. Sebanyak 21\% menunjukkan dengan menanam tanaman semangka petani lebih terdorong untuk meningkatkan ketrampilannya. Sebanyak 20,93\% menunjukkan bahwa dengan menanam tanaman semangka petani lebih terdorong untuk meningkatkan pengetahuannya, dan sebesar 20,18\% menunjukkan bahwa dengan menanam tanaman semangka petani lebih terdorong untuk meningkatkan kemampuan dirinya. Hal ini menunjukkan bahwa dorongan untuk kebutuhan harga diri dapat meningkatkan petani untuk melakukan budidaya tanaman semangka di lahan pasir pantai, Kabupaten Purworejo.

Berdasarkan Tabel 9 mengenai kebutuhan aktualisasi diri petani pada budidaya tanaman semangka di lahan pasir pantai,
Kabupaten Purworejo. Persentase terbesar pada kebutuhan aktualisasi diri terdapat pada dengan melakukan budidaya tanaman semangka di lahan pasir pantai petani dapat meningkatkan ketrampilannya yaitu sebesar $20,77 \%$. Sebesar $20,62 \%$ menyatakan bahwa dengan melakukan budidaya tanaman semangka petani dapat meningkatkan kemampuan diri dalam bertanam semangka, dan sebesar $20,24 \%$ menyatakan bahwa dengan melakukan budidaya tanaman semangka di lahan pasir pantai petani dapat mengikuti pelatihan-pelatihan yang diadakan oleh penyuluh. Hal ini menunjukkan bahwa kebutuhan aktualisasi diri petani dapat dilakukan dengan menanam tanaman semangka di lahan pasir pantai, Kabupaten Purworejo.

Mendasarkan Tabel 10 mengenai tingkat motivasi petani pada budidaya tanaman semangka di lahan pasir pantai, Kabupaten Purworejo bahwa motivasi petani semangka tergolong pada kategori sedang yaitu sebesar $50 \%$. Hal ini menunjukkan bahwa motivasi petani dalam melakukan budidaya tanaman semangka di lahan pasir pantai, Kabupaten Purworejo sudah bagus. Hal ini terlihat dari dorongan petani untuk tetap melakukan kegiatan budidaya tanaman semangka di lahan pasir pantai Kabupaten Purworejo.

Tabel 9. Kebutuhan aktualisasi diri petani pada budidaya tanaman semangka di lahan pasir pantai, Kabupaten Purworejo

\begin{tabular}{|c|c|c|}
\hline Pernyataan & Rata-rata skor & Persentase $(\%)$ \\
\hline $\begin{array}{l}\text { 1. Dengan melakukan budidaya tanaman semangka petani lebih } \\
\text { mudah untuk mengembangkan diri. }\end{array}$ & 4,25 & 19,11 \\
\hline $\begin{array}{l}\text { 2. Dengan melakukan budidaya tanaman semangka petani lebih } \\
\text { mudah dalam meningkatkan eksistensi mereka. }\end{array}$ & 4,28 & 19,27 \\
\hline $\begin{array}{l}\text { 3. Dengan melakukan budidaya tanaman semangka petani dapat } \\
\text { meningkatkan kemampuan diri dalam bertanam semangka. }\end{array}$ & 4,58 & 20,62 \\
\hline $\begin{array}{l}\text { 4. Dengan melakukan budidaya tanaman semangka di lahan pasir } \\
\text { pantai petani dapat meningkatan ketrampilannya. }\end{array}$ & 4,62 & 20,77 \\
\hline $\begin{array}{l}\text { 5. Dengan melakukan budidaya tanaman semangka di lahan pasir } \\
\text { pantai petani dapat mengikuti pelatihan-pelatihan yang diadakan } \\
\text { oleh penyuluh. }\end{array}$ & 4,5 & 20,24 \\
\hline Total & 22,23 & 100 \\
\hline
\end{tabular}

Sumber: Analisis Data Primer, 2019

Tabel 10. Tingkat motivasi petani pada budidaya tanaman semangka di lahan pasir pantai, Kabupaten Purworejo

\begin{tabular}{cccc}
\hline Kategori & Interval Kelas & Jumlah & Persentase \\
\hline Rendah & $18,6-19,8$ & 15 & 25 \\
Sedang & $19,9-21$ & 30 & 50 \\
Tinggi & $21,01-22,2$ & 15 & 25 \\
\hline & & 60 & 100,00 \\
\hline
\end{tabular}

Sumber: Analisis Data Primer, 2019 


\section{KESIMPULAN}

Sikap petani pada budidaya tanaman semangka di lahan pasir pantai Kabupaten Purworejo, Jawa Tengah dalam kategori sedang. Hal ini menunjukkan sudah banyak petani yang memiliki kecenderungan untuk membudidayakan tanaman semangka di lahan pasir pantai. Motivasi petani pada budidaya tanaman semangka di lahan pasir pantai Kabupaten Purworejo, Jawa Tengah dalam kategori sedang. Hal ini menunjukkan sudah banyak petani yang terdorong untuk membudidayakan tanaman semangka di lahan pasir pantai.

\section{DAFTAR PUSTAKA}

Creswell, J. W. (2012). Research Design: Pendekatan Kualitatif, Kuantitatif, dan Mixed. Yogyakarta: Pustaka Pelajar.

Djamal. (2015). Paradigma Penelitian Kualitatif. Yogyakarta: Pustaka Pelajar.

Hariadi, S. S. (2011). Dinamika Kelompok: Teori dan Aplikasinya untuk Analisis Keberhasilan Kelompok Tani sebagai Unit Belajar, Kerjasama, Produksi, dan Bisnis. Yogyakarta: Sekolah Pascasarjana Universitas Gadjah Mada.

Ife, J., \& Tesoriero, F. (2008). Community Development: Alternatif Pengembangan Masyarakat di Era Globalisasi. Yogyakarta: Pustaka Pelajar.

Khusna, M. K., Irianto, H., \& Setyowati. (2016). Analisis preferensi konsumen terhadap buah semangka di Kota Surakarta. Jurnal AGRISTA, 4(3), 461468.

Kusumaningrum, A., \& Widiyantono, D. (2018). Inovasi pengetahuan petani di lahan pasir pantai Kabupaten Purworejo. Jurnal Surya Agritama, 7(2), 8-19.

Miftakhul, A., Ariani, K., \& Hailitik, S.
(2017). Deskripsi sikap petani dalam Penerapan sistem tanam jajar legowo pada padi sawah. Agrica Ekstensia, 11(1), 22-31.

Morissan. (2016). Statistik Sosial. Jakarta: Kencana.

Prilierdi, A., Abubakar, R., \& Iskandar, S. (2015). Hubungan karakteristik petani terhadap pendapatan usahatani semangka (Citrullus vulgaris) di Desa Sugih Waras Kecamatan Muara Sugihan Kabupaten Banyuasin. SOCIETA, 4(1), 27-32.

Rahmawati, N., Triyono, \& Sriyadi. (2015). Motivasi kewirausahaan petani padi organik Di Kabupaten Bantul. SEPA(Jurnal Sosial Ekonomi Pertanian Dan Agribisnis), 12(1), 19-28.

Setyowati, I., Witjaksono, R., \& Kalily, R. (2020). Resistensi petani terhadap inovasi budidaya bawang merah di lereng Gunung Sumbing Temanggung. Jurnal Sosial Ekonomi Pertanian, 13(1), 53-64.

Sugiyono. (2010). Statistika untuk Penelitian. Bandung: Penerbit Alfabeta.

Sukanata, I. K., Dukat, \& Yuniati, A. (2015). Hubungan karakteristik dan motivasi petani dengan kinerja kelompok tani (Studi kasus Desa Cisaat Kecamatan Dukupuntang). Jurnal Agrijati, 28(1), 17-34.

Wilastinova, R. F. (2012). Analisis Pengaruh Faktor-Faktor Produksi Usahatani Semangka (Citrullus Vulgaris) Pada Lahan Pasir Di Pantai Kabupaten Kulon Progo. Surakarta.

Zainal, A., \& Cepriadi, M. D. (2015). Analisis faktor-faktor yang mempengaruhi motivasi petani dalam meningkatkan produksi padi di Desa Bungaraya Kecamatan Bungaraya Kabupaten Siak. Jurnal Jom Faperta, 2(2), 1-9. 